\title{
Courage and the care of children: Janusz Korczak
}

\author{
Richard B. Gunderman ${ }^{1}$
}

Received: 9 November 2020 /Revised: 9 November 2020 / Accepted: 16 December 2020 / Published online: 28 January 2021

(C) The Author(s), under exclusive licence to Springer-Verlag GmbH, DE part of Springer Nature 2021

No one would question that caring for children requires understanding, patience and compassion. But the story of a great pediatrician who devoted his life to enriching the lives of children for whom he eventually laid down his own life reminds us that, in our field, courage is an equally estimable virtue. His name was Janusz Korczak, and his work as a physician, educator, children's author, and defender and protector of children offers insight and inspiration to all pediatric specialists today.

Born in Warsaw, Poland, in 1879, Korczak was the son of a prominent attorney. During his teen years, his father descended into mental illness, leaving the family in straitened circumstances. Korczak began working as a tutor to sustain his family and continue his studies. He also began writing, publishing a satirical work on the raising of children. He studied at the Flying University, so named because the Russian authorities who ruled Poland at the time suppressed conventional academic institutions.

Between 1898 and 1904, Korczak studied medicine at the University of Warsaw, eventually specializing in pediatrics and working at a Warsaw children's hospital. After military service in the Russo-Japanese War, he studied in Berlin. Returning to Warsaw, he designed an orphanage for children, of which he became director. He gradually moved away from the practice of medicine and increasingly focused his energies on the orphanage.

Although interrupted by military service during World War I, Korczak instituted a number of innovations at the orphanage. For example, the children were encouraged to assume the role of citizens, operating their own legislature, establishing a court to handle infractions and disputes, and producing their own newspaper. After the war, he arranged for his Little Review, which had children on staff, to be distributed along

Richard B. Gunderman

rbgunder@iu.edu

1 Department of Radiology, Indiana University,

702 North Barnhill Drive, Room 1053, Indianapolis, IN 46077, USA with an adult newspaper. He also opened a summer camp that operated for 20 years.

Also in the 1920s, Korczak published a book for adults about caring for children called How to Love a Child, as well as a widely popular children's book, King Matt the First. Rising to fame, in the 1930s he hosted his own radio program, on which he discussed childrearing and promoted better treatment of children. With the outbreak of World War II in 1939, he volunteered for military service but was rejected because of his age.

Korczak rejected the views that children are savages who must be civilized or animals who have not yet attained the respect due to humanity. Instead, he argued that children are already human. In a work titled, "A Child's Right to Respect" (1925) [1], he wrote that all that is required for their inner potential for goodness and responsibility to be revealed is for them to receive the appropriate care:

Children are not the people of tomorrow but the people of today. They have a right to be taken seriously and to be treated with tenderness and respect. They should be allowed to grow into whoever they are meant to be. The "unknown person" inside of each one is our hope for the future.

Korczak's respect and love for children were reflected by the dim view he took of corporal punishment. He wrote:

Who would dare to shove, to pull, or strike an adult? And when, under what extraordinary circumstances? Yet how commonplace and innocent to slap a child, jerk them hard by the hand, or squeeze them painfully in affection [1].

Instead of looking down on children and disregarding their feelings and dignity, Korczak wrote, we should "bend over and lower ourselves to their level" [1].

Korczak was agnostic but of Jewish heritage. Faced with the anti-Semitism of Poland's Nazi occupiers, he engaged in numerous acts of civil disobedience. For example, he refused 
to wear an arm band bearing a Star of David, as required by the Nazi authorities. He also continued to wear his Polish officer's great coat, even though this placed him in danger. Yet when the Germans created the ghetto in Warsaw, he had no choice but to move his orphanage there.

Despite increasingly desperate circumstances in the ghetto, Korczak continued to operate the orphanage as he had before, ensuring that the children played an active role in running the institution. They staged plays and concerts attended by local people. During this time, Korczak kept a journal in which he recorded many of his experiences and those of the children, including their increasing hardships and injustices. Nevertheless, he continued to do his best to protect and nurture them.

Korczak's popularity presented him with numerous opportunities to escape the ghetto, but he refused them all, regarding it as his duty to remain with the children. In August 1942, German soldiers arrived to collect the nearly 200 children, with plans to transport them to an extermination camp. Korzcak again declined the opportunity to escape, insisting that he remain at their side. A heart-rending scene unfolded, as recounted in the Wladyslaw Szpilman's [2] book, The Pianist:

The children were to have been taken away alone. He had the chance to save himself, and it was only with difficulty that he persuaded the Germans to take him, too. He had spent long years of his life with children, and now, on this last journey, he would not leave them alone. He wanted to ease things for them. He told the orphans they were going out into the country, so they ought to be cheerful. At last they would be able to exchange the horrible, suffocating city walls for meadows of flowers, streams where they could bathe, woods full of berries and mushrooms. He told them to wear their best clothes, and so they came out into the yard, two by two, nicely dressed and in a happy mood.

When the group assembled at their point of departure, it is said that a German officer recognized Korczak as one of his favorite children's authors and offered to conduct him away to safety. Again, Korczak refused, instead boarding the train to Treblinka. Quoting again from Szpilman's [2] book, The Pianist:

I am sure that even in the gas chamber, as the Cyclon B gas was stifling childish throats and striking terror instead of hope into the orphans' hearts, the old doctor must have whispered with one last effort, "It's all right, children, it will be all right," so that at least he could spare his little charges the fear of passing from life to death.

Today there is an empty tomb in one of the Jewish cemeteries in Warsaw, bearing a sculpture of Korczak at the head of a procession of children. The children are in rows, each clutching a bag and a favorite toy, and in front is Korczak, holding the hand of a child, his head bent forward. Today a second version of the sculpture resides at a boarding school for children with special needs, which bears the name of Janusz Korczak.

Korczak believed that "children are not future people, because they are people already, whose souls contain the seeds of all those thoughts and emotions that we possess, and as they grow and develop, their growth must be gently directed." They should be "fully understood, respected, and loved, treated as partners and friends," and we should "behave toward each child as a respected, thinking, and feeling human being" [1].

Today's pediatric radiologists do not face choices as stark or momentous as Korczak's. By and large we do not live and work under threat of violence, and no extermination camp lies at the end of our tracks. And yet, every pediatric radiologist enjoys an opportunity to serve, advocate for, and defend children. In the fight for the least among us, sometimes courage is the most necessary virtue, and like Korczak, we too can find it in the faces of children.

\section{Compliance with ethical standards}

Conflicts of interest None

\section{References}

1. Korczak J (2017) A child's right to respect. Bye SG (trans). Rzecznik Praw Dziecka, Warsaw

2. Szpilman W (1999) The pianist: the extraordinary story of one man's survival in Warsaw, 1939-1945. Bell A (trans). Picador, New York

Publisher's note Springer Nature remains neutral with regard to jurisdictional claims in published maps and institutional affiliations. 